\title{
Peran Ibu dalam Pemberian Makanan Bergizi pada Balita Status Gizi Baik yang Kesulitan Makan
}

\author{
Rinda Dian Pratiwi ${ }^{1}$, Ni Ketut Martini ${ }^{2}$, Made Nyandra ${ }^{3}$ \\ ${ }^{1}$ Program Sarjana Kesehatan Masyarakat, Universitas Dhyana Pura, Bali \\ Email ${ }^{1}$ : rindadianpratiwi@gmail.com \\ 2,3 Departemen Kesehatan Masyarakat, Universitas Dhyana Pura, Bali
}

Tanggal Submisi: 8 Agustus 2020; Tanggal Penerimaan: 7 Desember 2020

\begin{abstract}
ABSTRAK
Pertumbuhan dan perkembangan balita adalah periode yang dikenal sebagai masa emas karena terjadi pertumbuhan yang sangat cepat, dan pembentukan kecerdasan balita. Hal ini terkait dengan asupan zat gizi yang diperoleh, apabila tidak terpenuhi bisa mengakibatkan gizi kurang Menurut Riskesdas 2013 Prevalensi status gizi balita sebesar 19,6\% kasus malnutrisi. Peran orang tua, khususnya Ibu yang berperan dalam pemenuhan gizi pada balita sebab di usia tersebut anak sulit makan yang dapat mengakibatkan kurang gizi (Underweight). Penelitian ini bertujuan untuk mengetahui peran Ibu dalam pemberian makanan bergizi pada balita status gizi baik yang kesulitan makan di Banjar Bhuana Merta Desa Tegal Harum Denpasar Barat. Penelitian ini adalah penelitian deskriptif dengan jenis penelitian kualitatif, dan menggunakan consecutive sampling. Sampel adalah $10 \mathrm{Ibu}$ balita yang sesuai dengan kriteria. Analisis menggunakan triangulasi teknik dan waktu. Hasil Penelitian adalah seluruh Ibu telah berperan dalam pemilihan jenis bahan makanan bergizi pada balitanya, namun belum memberikan makanan yang bervariasi. Mayoritas Ibu belum menyajikan hidangan yang menarik untuk balita dari segi warna, rasa, cara pengolahan, bentuk makanan, serta alat makan belum menggunakan khusus balita. Mayoritas Ibu memberikan makan sesuai dengan keinginan balita, yaitu makan sambil bermain. Kesimpulan penelitian ini adalah peran pemilihan dan menciptakan situasi makan telah dilakukan Ibu balita, hanya peran penyajian yang belum dilakukan.
\end{abstract}

Kata Kunci : Peran ibu, sulit makan, balita

\section{ABSTRACT}

The growth and development of toddlers as the golden age period because there is very fast growth, and the esthablisment of toddler intelligence. This is related to the intake of nutrients obtained, can cause malnutrition. According to Riskesdas 2013, the prevalence of toddlers nutritional status was $19.6 \%$ of malnutrition cases. The role of parents especially mothers who play a role in nutrition intake to toddlers, because at that age children have difficulty eating which can cause malnutrition (Underweight). The purpose of this study is to determine the role of mothers in providing nutritious food for toddlers with good nutritional status who have difficulty eating in Banjar Bhuana Merta Tegal Harum Village, West Denpasar. This research is a descriptive study with qualitative research type, and uses consecutive sampling. The sample is 10 mothers of toddlers who fit the criteria. Analysis using triangulation techniques and time. The results of the study are all mothers have a role in the selection of 
nutritious food ingredients on their toddlers, but have not provided a varied diet. The majority of mothers have not served interesting dishes for toddlers in terms of color, taste, processing methods, shape of food, and cutlery not yet using special toddlers. The majority of mothers provide food in accordance with the wishes of toddlers, namely eating while playing. The conclusion of this research is the role of selecting and creating a feeding situation has been done by mothers of toddlers, only the role of presentation has not been done

Keywords : Mother's role, difficult to eat, toddlers

ISSN 1979-7621 (Print). ISSN 2620-7761 (Online)

DOI 10.23917/jk.v14i2.11759

\section{PENDAHULUAN}

Pertumbuhan dan perkembangan balita adalah periode yang dikenal sebagai masa emas karena terjadi pertumbuhan yang sangat cepat, dan pembentukan kecerdasan balita. Hal ini terkait dengan asupan zat gizi yang diperoleh karena apabila tidak terpenuhi dapat mengakibatkan gizi kurang (Depkes RI, 2005). 50\% dari kematian balita disebabkan karena kekurangan nutrisi. Kekurangan nutrisi menempatkan balita beresiko tinggi terhadap kematian yang disebakan karena infeksi penyakit (UNICEF, 2015).

Di Indonesia Prevalensi status gizi balita berdasarkan Riskesdas 2013 sebesar $19,6 \%$ kasus malnutrisi , yaitu gizi buruk $5,7 \%$, dan gizi kurang $13,9 \%$, angka ini menunjukkan sasaran MDGS 2015 sebesar 15,5\% belum tercapai (Kemenkes RI, 2013). Pada tahun 2014 prevalensi gizi kurang dan gizi buruk Provinsi Bali masing-masing sebesar 10,2\% dan 3\%, angka ini lebih kecil dibandingkan gizi kurang dan buruk secara Nasional. Balita gizi buruk yang terdeteksi di tahun 2014 sebesar 96 orang dan telah memperoleh perawatan $100 \%$. Tetapi, terdapat kesenjangan antara jumlah kasus yang diperoleh dengan prevalensi kasus gizi buruk menggunakan indikator $\mathrm{BB} / \mathrm{TB}$ sebesar $3,4 \%$, dan terdapat $20 \%$ balita yang belum dimonitor status gizinya yang dapat menyebabkan terjadinya masalah-masalah kesehatan (Dinkes Bali, 2015). Begitu juga dengan kota Denpasar, data dari Renstra
Dinas Kesehatan kota Denpasar 2010-2015 menunjukkan bahwa prevalensi gizi kurang dan buruk di kota Denpasar sudah melebihi target nasional, walaupun demikian realisasi penanganan kasus gizi kurang dan buruk di kota Denpasar belum maksimal yaitu hanya $50 \%$ dari target yang diharapkan (Dinkes Denpasar, 2014).

Peran orang tua, khususnya ibu dalam merawat dan mendidik terutama dalam pemenuhan gizi pada balita sebab pada usia tersebut anak susah makan (Wijayanti, 2010). Penelitian oleh (Fitriani et al., 2009) di Palembang yaitu 55,4 \% anak usia 3-5 tahun memilih-milih makanan atau makan makanan tertentu saja, dan kebiasaan anak hanya ngemil jajanan. Dimulai dari usia 1 sampai dengan 5 tahun akan terjadi perkembangan psikologis menjadi anak yang lebih mandiri, dan bisa bersosialisasi dengan lingkungan, serta bisa lebih meluapkan emosinya, yaitu mudah menangis, dan berteriak jika anak tidak nyaman. Ciri perkembangan yang terjadi ini juga berkaitan dengan pola makannya.

Gangguan ini dapat berkembang menjadi masalah kesulitan makan yang berdampak pada pertumbuhan dan perkembangan anak, yaitu mengalami kurang gizi (Underweight) karena sedikitnya makanan yang dikonsumsi sehingga kebutuhan nutrisinya tidak mencukupi (Rohmasari, 2013). Hal serupa terjadi pada balita di Banjar Bhuana Merta yang merupakan sebuah dusun di Denpasar Barat. 
Semua balita di Banjar ini memiliki status gizi baik dengan presentase $100 \%$ tetapi banyak yang memiliki problema makan (SIP Dusun Bhuana Merta, 2015). Maka dari itu, peran ibu untuk mengatasi masalah ini sangat dibutuhkan sebagai upaya preventif agar status gizi balita tetap baik sehingga tujuan penelitian ini adalah untuk mengetahui peran ibu dalam pemberian makanan bergizi pada balita status gizi baik yang kesulitan makan.

\section{METODE}

Penelitian ini adalah penelitian deskriptif dengan jenis penelitian kualitatif. Populasinya yaitu seluruh ibu yang mempunyai balita berstatus gizi baik di Banjar Bhuana Merta Desa Tegal Harum Denpasar Barat pada Bulan Mei 2016 berjumlah 46 orang. Teknik penentuan sampelnya adalah consecutive sampling dengan kriteria yang ditetapkan, yaitu ibu yang berpendidikan minimal SMP dengan harapan bisa berbahasa Indonesia dan bisa baca tulis, memiliki balita yang kesulitan makan, ibu yang datang ke posyandu saat skrining balita yang kesulitan makan dilaksanakan, dan bersedia menjadi responden. Semua subyek yang memenuhi kriteria diikutsertakan sampai jumlahnya mencukupi sehingga didapatkan jumlah sampel sebanyak 10 orang. Peneliti mengumpulkan informasi tentang calon subyek peneliti pada saat posyandu dilaksanakan, kemudian melakukan skrining balita yang kesulitan makan. Setelah itu, peneliti meminta kesediaan untuk berpartisipasi dalam penelitian.

Metode pengumpulan data dilakukan dengan menggunakan wawancara mendalam (indeepth interview) dan observasi non partisipatif. Alat yang digunakan untuk mengumpulkan data adalah pedoman Indeepth interview (wawancara mendalam) yang diadaptasi dari Saraswati (2012) dengan modifikasi oleh peneliti, pedoman observasi, alat penunjang (handphone) sebagai alat perekam. Pengolahan data dilakukan dengan cara hasil rekaman data yang didapat kemudian didengarkan kembali serta dibuatkan transkipnya dalam bentuk tulisan. Kemudian dilakukan pengelompokkan berdasarkan kategori, tema, dan pola jawaban (pembuatan matriks), dan menarik kata kunci. Triangulasi teknik dan waktu dilakukan untuk menganalisis data. Triangulasi dilakukan sebagai validitas dan kredibilitas data.

\section{HASIL DAN PEMBAHASAN Karakteristik Responden}

Pada penelitian ini, subyek yang terlibat adalah Ibu balita. Mayoritas umur ibu (40\%). adalah 30 tahun Mayoritas pekerjaan ibu (100\%) sebagai ibu rumah tangga sehingga mereka mengasuh anak sendiri, dan pendidikan terakhir ibu sebagian besar (90\%) adalah SMA. Mayoritas ibu (50\%) memiliki anak usia 4 tahun dan sebagian besar (60\%) bukan merupakan anak pertama atau lebih dari satu anak.

\section{Skrining Kesulitan Makan pada Balita Status Gizi Baik}

Berdasarkan hasil skrining kesulitan makan didapatkan hasil bahwa mayoritas balita $(70 \%)$ memiliki sifat hanya ingin makan makanan kesukaannya, dan frekuensi kesulitan makan yang dialami balita mayoritas (70\%) adalah kadang-kadang, serta Ibu mulai menyadari anak mereka mengalami kesulitan makan sejak usia 2 tahun.

\section{Peran Ibu dalam Pemilihan Jenis Bahan Makanan Bergizi pada Balita Status Gizi baik yang Kesulitan Makan}

Berdasarkan hasil penelitian, seluruh responden $(100 \%)$ mengatakan memilihkan jenis bahan makanan bergizi di menu makan anak mereka. Seluruh responden (100\%) memilih bahan makanan bergizi karbohidrat protein, lemak, serta vitamin yang terkandung dalam menu nasi, ayam goreng, dan sayur sup, yang tergambar dalam kutipan wawancara di bawah ini :

"Iya ada, biasanya nasi, ayam goreng, ikan laut, sayur tapi jarang dia tidak suka sayur, tempe goreng suka dia” (R04W04).

Hal ini juga terlihat pada saat observasi dilakukan. Seluruh responden memilihkan 
bahan makanan bergizi untuk anak balita mereka. Pada umumnya jenis bahan makanan bergizi pada menu makan balita tidak banyak jenisnya. Hal ini dapat terlihat pada kutipan wawancara berikut:

"Iya kadang nasi sama ikan, nasi telur, kalau sayur dia tidak mau paling kuahnya aja" (R07W07).

Peran Ibu dalam pemilihan jenis bahan makanan bergizi sangat penting untuk anak balita mereka karena secara spesifik makanan memiliki fungsi "BIOLOGIS". Makanan terdiri dari beberapa unsur (protein, lemak, karbohidrat, vitamin, dan mineral) yang memiliki 3 tugas utama yaitu zat pembangun, sumber tenaga, dan zat pengatur. Ketiganya harus ada dalam tubuh (Waryana, 2010). Begitu juga dengan penelitian Sriwahyuni tahun 2011 di Semarang bahwa untuk membentuk pola makan yang baik pada anak balita adalah dengan menyediakan bahan makanan yang bergizi dan beraneka ragam. Hal ini dapat dilakukan sebagai salah satu upaya mengatasi kesulitan makan pada balita.

Hasil penelitian juga menunjukkan bahwa mayoritas responden (80\%) mengatakan jenis bahan makanan bergizi favorit anak balita mereka adalah yang mengandung protein dan lemak, karena sebagian besar balita menyukai makanan yang pada umumnya digoreng seperti ayam goreng, telur goreng, dan tempe goreng. Berikut kutipan wawancara mendalam yang menggambarkan hasil ini :

"Itu benar mba ayam, kalau yang ayam itu kulit-kulitnya yang kering-kering, tidak mau dagingnya, pokoknya senengnya kulit ayam, yang kering-kering kayak telur juga telur goreng, direbus tidak mau” (R07W07).

Peran ibu dalam pemilihan variasi jenis bahan makanan bergizi untuk menu makan balita sangat penting untuk memenuhi kebutuhan makannya, dari segi kuantitas dan nilai gizinya. Apabila balita diperkenalkan dengan berbagai jenis makanan sejak dini, pola makan dan kebiasaan makan di masa yang akan datang adalah makanan beragam (Ernawati, 2015). Penelitian yang dilakukan di Bekasi oleh
Saraswati (2012) bahwa salah satu faktor yang melatarbelakangi perilaku sulit makan adalah variasi jenis bahan makanan yang terbatas atau monoton setiap harinya pada menu makan anak. Makanan balita yang mengandung lemak harus dibatasi dalam segi kuantitas karena kurang baik bagi anak. Maka dari itu, peran Ibu dalam pengaturan jenis dan bahan makanan bergizi favorit yang dikonsumsi balita harus dilakukan sebaik mungkin untuk membentuk kebiasaan dan kesukaan anak terhadap makanan beragam atau tidak terbatas variasinya (Ernawati, 2015).

Peran Ibu dalam Penyajian Makanan bergizi pada Balita Status Gizi Baik yang Kesulitan Makan

Pada saat menyajikan menu makanan bergizi untuk anak balita adalah dengan menggunakan piring biasa sebagai tempat makan seperti orang dewasa pada umumnya. Berikut kutipan wawancara yang menggambarkan hasil penelitian ini :

"Biasa di piring soalnya disuapi, kalau tidak disuapi tidak mau makan dia" (R01W01).

Hasil observasi yang dilakukan terhadap responden tidak jauh berbeda, mayoritas ibu $(60 \%)$ menyajikan menu makan untuk anak mereka di piring yang biasa digunakan pada umunya tanpa ada variasi gambar khas balita pada tempat makan. Sebagian besar ibu menganggap variasi tempat makan anak balita mereka tidak terlalu penting.

Hasil lain yang diperoleh dari wawancara mendalam terhadap responden adalah mayoritas ibu menyajikan menu makan bergizi hanya memperhatikan rasa yang disukai oleh anak mereka, dan ibu tidak memperhatikan masalah warna yang menarik dari menu makan. "Ya sukanya yang ada rasa garamnya, kalau warna seperti biasanya pada umumnya yang penting ada rasanya" (R05W05).

Peran Ibu dalam penyajian makanan merupakan salah satu hal penting yang tak boleh terlupakan oleh ibu dalam pemberian makanan bergizi pada balita. Penyajian makanan dapat membuat selera makan anak bertambah besar. Penyajian makanan dapat 
dibuat menarik baik dari variasi warna, dan rasa. Pemakaian variasi warna, dan rasa dari makanan yang disajikan bisa diterapkan dari bahan yang berbeda maupun yang sama. Di samping itu juga dapat memakai alat makan yang lucu dan menarik sehingga selain anak ingin untuk makan, anak tertarik untuk belajar makan sendiri (Ernawati, 2015). Berdasarkan hasil penelitian dapat terlihat bahwa peran ibu dalam penyajian makanan bergizi dalam hal variasi tempat, warna, dan rasa belum terlaksana dengan baik.

Peran ibu dalam memvariasikan pengolahan dan bentuk makan yang disajikan pada menu makan balita diperoleh hasil, yaitu mayoritas responden mengatakan pengolahan makan setiap harinya adalah lebih sering dengan cara digoreng, dan ibu tidak memvariasikan bentuk makanan anak mereka. Meskipun mayoritas responden tidak mevariasikan pengolahan dan bentuk pada makanan dalam menu makan, peran ibu dalam pemberian makanan bergizi diimbangi dengan memberikan camilan yang bergizi, walaupun intensitas pemberiannya tidak setiap hari seperti kutipan wawancara mendalam berikut :

"Selingannnyaa sih ada pagi sampai sore susu kuat sekali, biskuit-biskuit begitu, kecap campur telur, apa saja dikasih yang penting mau makan" (R07W07).

Proses pengolahan makanan memiliki beberapa kelebihan, yaitu meningkatkan nilai gizi dan daya cerna, memperbaiki cita rasa dan aroma, serta daya simpan menjadi lebih panjang (Ernawati, 2015). Begitu juga dengan penelitian yang dilakukan oleh Novitasari (2012) yaitu orang tua masih merasa kesulitan dalam mengolah makanan sehat bagi anak mereka. Namun, ada perbedaan hasil penelitian tentang variasi bentuk makanan bergizi yang dilakukan oleh Sriwahyuni (2011) bahwa cara penyajian makan yang dilakukan ibu adalah dengan memodifikasi bentuk makanan supaya menarik minat makan anak. Hal ini dapat disebabkan salah satunya karena perbedaan pengetahuan ibu tentang cara penyajian makanan bergizi pada balita yang kesulitan makan.

Camilan bergizi juga penting diberikan pada menu makan anak setiap harinya di sela makan pokok, karena balita mengalami kesulitan makan sehingga tidak sesuai dengan porsi makannya. Fungsi lainnya adalah memperkenalkan aneka jenis bahan makanan bergizi, memenuhi kebutuhan zat-zat gizi yang mungkin kurang dalam makanan utamanya, serta melengkapi kekurangan kalori karena banyaknya aktivitas anak pada usia balita. Namun, pemberian camilan yang berlebihan pun tidak baik karena mengganggu nafsu makanannya (Waryana, 2010).

\section{Peran Ibu dalam Menciptakan Situasi yang Membuat Balita yang Kesulitan Makan Mau Makan Makanan yang Bergizi}

Peran ibu dalam menciptakan situasi makan yang menyenangkan pada balita adalah dengan cara makan sambil bermain. Hal ini dilakukan oleh mayoritas responden seperti pada kutipan wawancara mendalam berikut :

"Iya paling suka sambil jalan-jalan, dan sambil bermain" (R06W06).

Sebagian besar ibu (60\%) selalu menemani anak mereka saat makan. Apabila ibu sedang tidak di rumah mayoritas responden (70\%) mengatakan yang menemani anak mereka saat makan adalah keluarga terdekat. Berdasarkan observasi yang dilakukan terhadap responden menunjukkan hasil yang sama, yaitu sebagian besar ibu menciptakan situasi makan menyenangkan dengan cara sambil bermain, dan seluruh responden terlihat menemani dengan penuh perhatian, dan sabar saat anak balita mereka makan.

Hasil penelitian ini sejalan dengan teori yang dijelaskan Waryana (2010), bahwa suasana makan yang menyenangkan dapat diciptakan di dalam rumah bisa sambil bermain dengan nonton televisi, mendengarkan lagu kesenangan, atau makan bersama-sama keluarga yang lain. Situasi ini diharapkan dapat menambah nafsu makan anak. Hal penting lain yang perlu diperhatikan adalah tidak disarankan 
memaksa anak untuk menghabiskan makanannya, orang tua khususnya ibu harus telaten saat memberi makan anak, lebih baik waktu makan disamakan dengan waktu makan keluarga karena anak antusias untuk menghabiskan makanannya, serta menghindari percakapan yang kurang menyenangkan mengenai suatu jenis makanan. Penelitian yang dilakukan oleh Sriwahyuni (2011) juga menunjukkan hasil yang sama bahwa bahwa peran situasi yang dilakukan ibu adalah dengan makan sambil bermain.

\section{KESIMPULAN}

Seluruh ibu telah melakukan perannya dalam pemilihan jenis bahan makanan bergizi pada balita status gizi baik yang kesulitan makan. Namun, ibu tidak memvariasikan jenis bahan makanan bergizi setiap harinya pada menu makan.
Kemudian, peran penyajian yang dilakukan mayoritas ibu dalam pemberian makanan bergizi pada balita status gizi baik yang kesulitan makan belum terlaksana, karena ibu tidak memvariasikan cara penyajian menu makan untuk anak balita mereka dari segi tempat makan, warna, rasa, pengolahan, dan bentuk makanan. Sedangkan peran situasi menyenangkan saat makan yang dilakukan Ibu sudah dilaksanakan dengan baik. Peran situasi tersebut adalah sebagian besar makan sambil bermain, yang merupakan situasi favorit mayoritas balita dalam penelitian ini. Disarankan perlu dilakukan sosialisasi tentang cara pemberian makanan bergizi pada balita status gizi baik yang kesulitan makan.

\section{UCAPAN TERIMA KASIH}

Ucapan terima kasih Kepala Dusun, serta Kader Posyandu Banjar Bhuana Merta.

\section{DAFTAR PUSTAKA}

Denpasar, Dinkes. 2014. Rencana Strategis Dinas Kesehatan Kota Denpasar 2010-2015, Dinas Kesehatan Kota Denpasar, p. 1-56.

Depkes RI 2005. Pedoman Pelaksanaan Stimulasi, Deteksi, dan Intervensi Dini Tumbuh Kembang Anak.

Dinkes, Bali. 2015. Profil Kesehatan Provinsi Bali Tahun 2014, Journal of Chemical Information and Modeling, 53(9), p. 1689-1699. DOI: 10.1017/CBO9781107415324.004.

Ernawati, L. 2015. Faktor-Faktor yang Mempengaruhi pola pemberian makan pada Balita Keluarga Petani di Desa Srimartani, Kecamatan Piyungan, Kabupaten Bantul, Yogyakarta, Universitas Negeri Yogyakarta.

Fitriani, F., Febry, F. and Mutahar, R. 2009. Gambaran Penyebab Kesulitan Makan pada Anak Prasekolah Usia 3-5 Tahun di Perumahan Top Amin Mulya Jakabaring Palembang Tahun 2009, Jurnal Publikasi Ilmiah Fakultas Kesehatan Masyarakat Universitas Sriwijaya. Available at: http://eprints.unsri.ac.id/id/eprint/58.

Kemenkes RI 2013. Hasil Riset Kesehatan Dasar Kementerian RI 2013, Proceedings, Annual Meeting - Air Pollution Control Association, 6. DOI: 1 Desember 2013.

Merta, S. D. B. 2015. SIP Status Gizi Balita.

Rohmasari, A. 2013. Faktor-Faktor yang Mempengaruhi Sulit Makan pada Balita di Kelurahan Tonatan, Kecamatan Ponorogo, Kabupaten Ponorogo., Universita Muhammadiyah Ponorogo.

Sriwahyuni 2011. 2011. Peran Ibu dalam Mengatasi Kesulitan Makan pada Balita di Desa Kaba Utara R.T. 07 R.W. XII Kelurahan Tandang, Kecamatan Tembalang Semarang, Unimus.

UNICEF 2015. Undernutrition Contributes to Nearly Half of All Death in Children Under 5 and Widespread in Asia and Africa. Available at: 
R D Pratiwi, N K Martini \& M Nyandra / Jurnal Kesehatan 14 (2) 2021, 119-125

https://data.unicef.org/resources/children-in-africa-2015/.

Waryana 2010. Gizi Reproduksi. Yogyakarta: Pustaka Rihana.

Wijayanti, E. 2010. Peran Ibu terhadap Pemberian Gizi pada Anak Usia 1-5 Tahun di Desa Sumurgeneng Wilayah Kerja Puskesmas Jenu Kabupaten Tuban, stikesnu. 